\title{
MEMBANGUN MOTIVASI DALAM MEMULAI KARIR DI ERA TURBULENSI
}

\author{
Mufidatul Islamiyah ${ }^{1}$, Risa Santoso², Vivi Aida Fitria ${ }^{3}$, Azwar Riza Habibi $^{4}$, \\ Lukman Hakim ${ }^{5}$ \\ 1,2,3,4,5 Institusi Teknologi Dan Bisnis Asia Malang \\ ${ }^{*}$ Corresponding author \\ E-mail: mufidatul014@gmail.com (Mufidatul Islamiyah)*
}

Article History:

Received: 28-7-2020

Revised: 5-8-2020

Accepted: 5-8-2020

Keywords:

\begin{abstract}
Adanya perubahan gaya hidup tersebut menyebabkan perubahan kondisi pada hampir semua bidang. Salah satunya pada kebutuhan kondisi dunia kerja. Oleh karena itu dibutuhkan sebuah informasi dan motivasi dalam menghadapi kondisi di era turbulensi. Era turbulensi adalah era dimana menghadapi ketidakpastian kondisi global yang diperkirakan terus berlangsung satu hingga dua tahun ke depan. Dengan adanya permasalahan tersebut, maka diadakan kegiatan pengabdian masyarakat tentang bagaimana membangun motivasi dalam membangun karir di era turbulensi. Adapun kegiatan pengabdian ini adalah webinar gratis untuk mahasiswa yang bekerjasama dengan Universitas Negeri Malang.
\end{abstract}

webinar, perubahan kondisi, turbulensi

\section{Pendahuluan}

Pandemi virus corona yang sampai saat ini masih berlanjut, mengakibatkan kebiasaan dan gaya hidup masyarakat berubah. Empat gaya hidup baru yang terjadi pada masyarakat saat ini diantaranya stay at home lifestyle, dengan adanya physical distancing hal ini mengakibatkan tetap tinggal di rumah menjadi solusi terbaik bagi masyarakat, sehingga belanja online menjadi satu alternatif bagi banyak orang, Back to the Bottom of the Pryramid mengacu pada piramida Maslow, kebutuhan konsumen bergeser dari puncak piramida (aktualisasi diri) ke dasar piramida (makanan, kesehatan dan keamanan jiwa raga), Go Virtual, hampir semua kegiatan yang awalnya dapat dilakukan secara langsung sekarang beralih ke media virtual/digital dan yang terakhir Emphatic society, dengan banyaknya korban nyawa akibat COVID-19, melahirkan masyarakat baru yang penuh empati, welas asih, dan sarat solidaritas social (Yuswohady et al, 2020).

Adanya perubahan gaya hidup tersebut menyebabkan perubahan kondisi pada hampir semua bidang. Salah satunya pada kebutuhan kondisi dunia kerja. Oleh karena itu dibutuhkan sebuah informasi dan motivasi dalam menghadapi kondisi di era turbulensi. Era turbulensi adalah era dimana menghadapi ketidakpastian kondisi global yang diperkirakan terus berlangsung satu hingga dua tahun ke depan. Dengan adanya permasalahan tersebut, maka diadakan kegiatan pengabdian masyarakat tentang bagaimana membangun motivasi dalam membangun karir di 
era turbulensi. Adapun kegiatan pengabdian ini adalah webinar gratis untuk mahasiswa yang bekerjasama dengan Universitas Negeri Malang.

Untuk itu sangat perlu diadakan sebuah kegiatan seminar bagi mahasiswa khususnya dalam mempersiapkan masa depan mereka di era turbulensi. Bagaimana mempersiapkan karir mereka pada keadaan yang tidak bisa diprediksi, dimana semua dilakukan secara online, kenaikan pemakaian media social sebagai media entertainment dan komunikasi serta perkembangan digital yang sangat pesat. Sehingga mahasiswa menjadi lebih siap untuk tetap produktif dan inovatif dimasa pandemi Covid 19 ini.

\section{Metode}

\section{Tahapan Pelaksanaan}

Tahapan atau langkah-langkah yang ditempuh guna melaksanakan solusi atas permasalahan yang dihadapi oleh mitra pengabdian kepada masyarakat ditunjukkan pada Gambar 1.

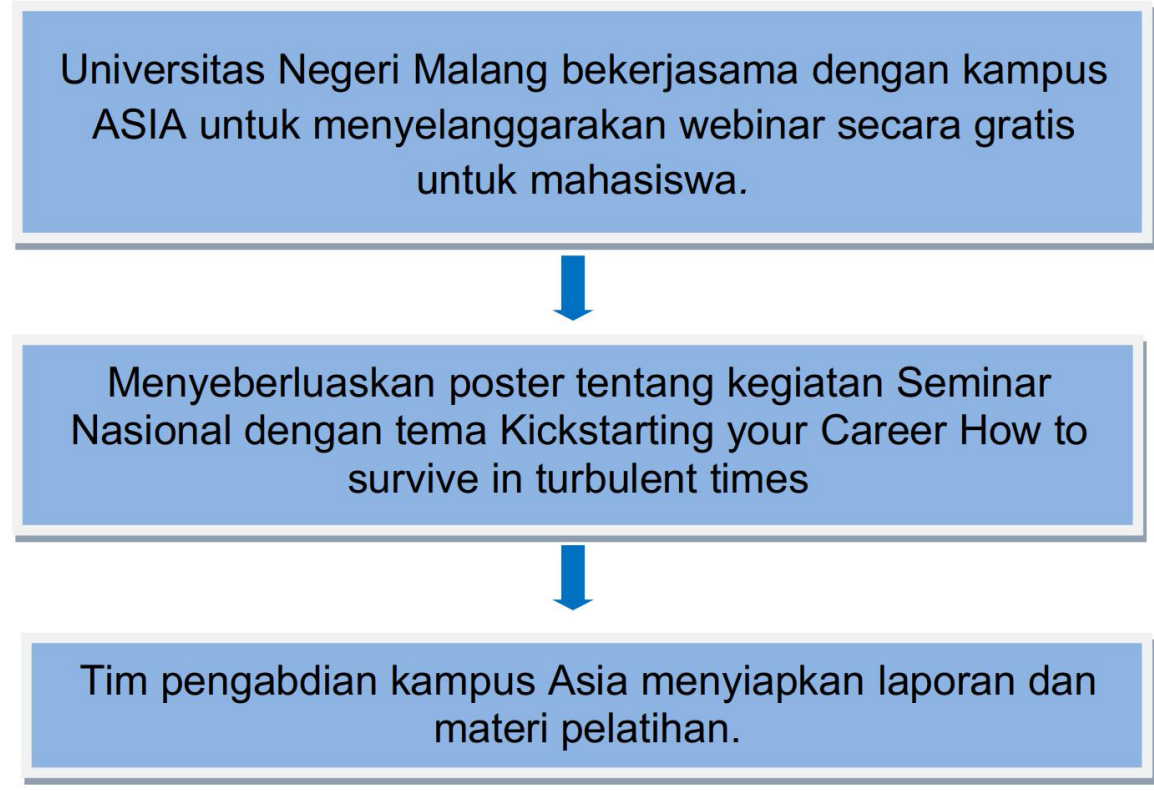

\section{Pelaksanaan Pelatihan}

\section{a. Materi kegiatan webinar dan Jumlah Pertemuan dengan Mitra}

Saat pelaksanaan pengabdian masyarakat dilakukan diskusi dengan mitra sebagai tahap awal untuk menemukan solusi tentang permaslahan yang terjadi. Diharapkan pengabdian ini mampu memberikan wawasan dan motivasi kepada mahasiswa. Berikut adalah rincian kegiatan yang akan dilaksanakan:

Sesi I : Pemberian mentimeter untuk mengetahui kondisi peserta 
b. Pemateri

Sesi II : Pemberian materi

Sesi III : Pemberian mentimeter tentang feedback dari peserta

Webinar diberikan oleh tim pemateri Pengabdian kepada Masyarakat tentang pemberian motivasi kepada mahasiswa dalam menghadapi era turbulensi.

\section{c. Tempat dan Waktu Latihan}

Pelaksanaan kegiatan dan waktu pelaksanaan kegiatan akan dilakukan sesuai dengan paparan berikut:

a. Akses link zoom meeting.

b. Waktu menyesuaikan jadwal

\section{d. Partisipasi Mitra}

Mitra Pengabdian adalah Universitas Negeri Malang. Adapun partisipasi mitra pengabdian adalah membuat dan menyebarkan poster kegiatan webinar, menyediakan link zoom dan mendata peserta webinar. Tim pengabdian akan menyiapkan materi untuk pelatihan.

\section{Hasil}

Pengabdian ini menghasilkan sebuah kegiatan Seminar Nasional secara online dengan tema Kickstarting your Career How to survive in turbulent times. Berikut adalah materi pada kegiatan webinar tersebut:

1. Pendahuluan dan penyampaian $\mathrm{CV}$ pemateri
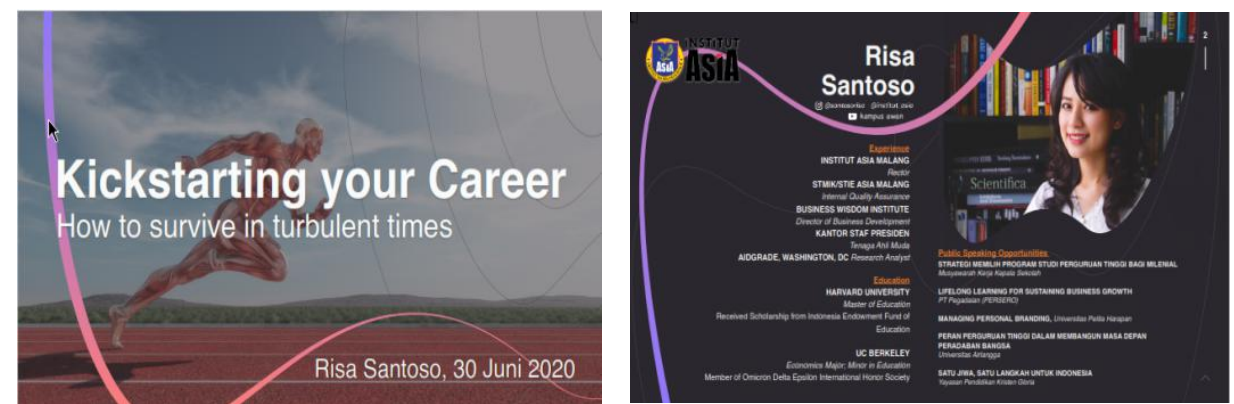

2. Pengetahuan tentang perubahan gaya hidup di era turbulensi
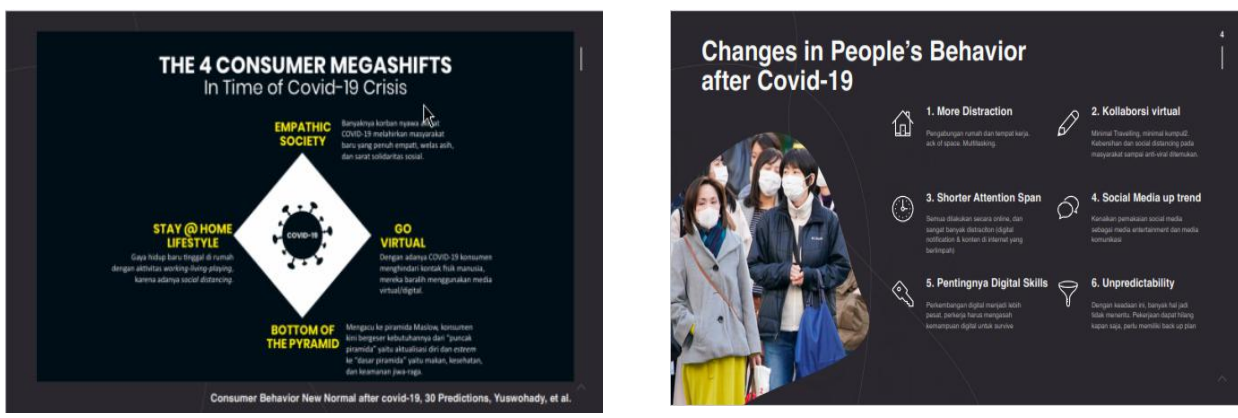
JPM: Jurnal Pengabdian kepada Masyarakat Institut Teknologi dan Bisnis Asia Malang Vol. 1, No. 1, Mei 2020, pp. 14-18

3. Tips dan trik membangun karir di era turbulensi
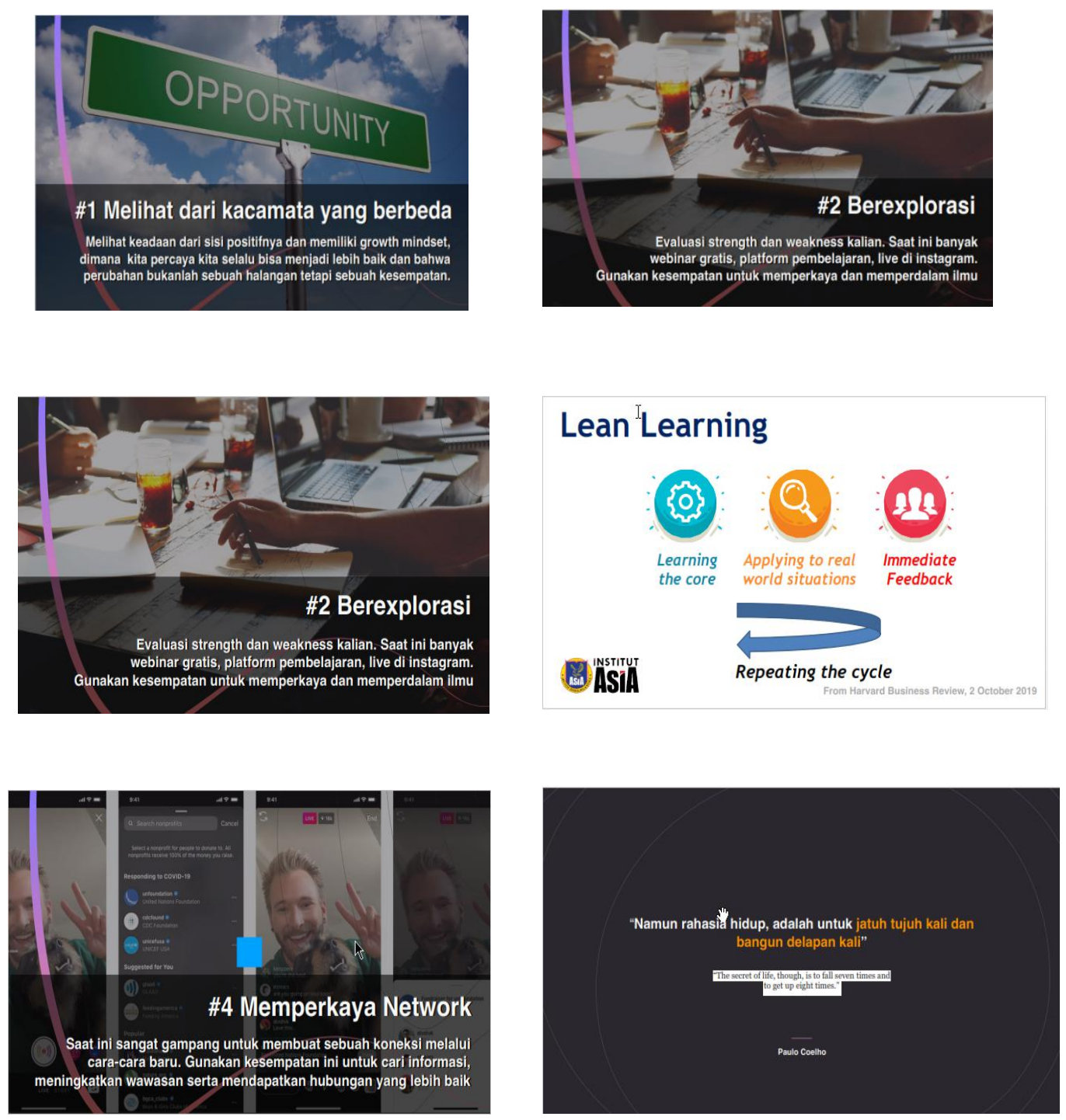

\section{Diskusi}

Berdasarkan ketertarikan dan minat yang tinggi yang ditunjukan oleh peserta dan mitra, tim pelaksana pengabdian berencana untuk memberikan pelatihan dengan bahasan yang lain supaya antara Institut Asia dan mitra dapat memberikan pengetahuan dan pengalaman yang banyak kepada masyarakat. 


\section{Kesimpulan}

Demikian laporan program Pengabdian Kepada Masyarakat yang dapat kami susun. Mudah-mudahan hal ini dapat jadikan acuan bagi Penanggung jawab kerja LP2M di lingkungan Institut Asia mengenai pelaksanaan kegiatan Pengabdian kepada Masyarakat. Selain itu hal ini juga diharapkan dapat menjadi panduan bagi seluruh dosen dalam melaksanakan kegiatan Pengabdian kepada Masyarakat dengan mempertimbangkan standar yang telah ditetapkan.

Segala sesuatu yang akan disampaikan kepada khalayak umum tentang materi pengabdian masyarakat pada periode ini dapat menjadikan sebagai manfaat dalam melakukan aktifitas dikalangan masyarakat khususnya tenaga pendidik dalam mengembangkan bahan ajar secara online.

\section{Daftar Referensi}

Yuswohady et al, 2020. E-BOOK 30 Consumer Behavior Shiftings Welcome the New Normal.

Purwanto, Djoko. (2003). Komunikasi Bisnis.Jakarta:Erlangga.

Sutomo, Erwin. (2007). 9 Presentasi Kreatif dengan Power Point.Yogyakarta: Andi Offset

Triwahyuni, T. C. dan Abdul Kadir. (2004). Presentasi Efektif dengan Microsoft

Power Point. Yogyakarta: Andi Offset. 